\title{
Understanding the Consumers' Behavior Intention in Using Green Ecolabel Product through Pro-Environmental Planned Behavior Model in Developing and Developed Regions: Lessons Learned from Taiwan and Indonesia
}

\author{
Ilma Mufidah ${ }^{1,2}$, Bernard C. Jiang ${ }^{1}$, Shu-Chiang Lin ${ }^{1}$, Jacky Chin ${ }^{1,3}$, Yulia Puspa Rachmaniati ${ }^{1}$ \\ and Satria Fadil Persada ${ }^{4, *}$ \\ 1 Department of Industrial Management, National Taiwan University of Science and Technology, 43, \\ Keelung Rd, Da'an Dist, Taipei 106, Taiwan; ilma.mufidah1@gmail.com (I.M.); \\ bcjiang@mail.ntust.edu.tw (B.C.J.); slin_100@hotmail.com (S.-C.L.); d10301801@mail.ntust.edu.tw (J.C.); \\ m10401835@mail.ntust.edu.tw (Y.P.R.) \\ 2 Department of Industrial Engineering, Telkom University, Bandung 40257, Indonesia \\ 3 Department of Mechanical Engineering, Atma Jaya Catholic University, Jakarta 12930, Indonesia \\ 4 Department of Business Management, Institut Teknologi Sepuluh Nopember (ITS), \\ Surabaya 60111, Indonesia \\ * Correspondence: satriafadil@mb.its.ac.id; Tel.: +62-31-5994251 (ext. 1072)
}

Received: 3 March 2018; Accepted: 19 April 2018; Published: 4 May 2018

\begin{abstract}
An ecolabel product is an environmentally friendly substance that can be selected to maintain environmental sustainability. Both developed and developing regions are promoting the use of green products. The current study aimed to know the behavior intention on ecolabel product usage from citizens in developing and developed regions. The extended Theory of Planned Behavior, known as Pro-Environmental Planned Behavior Model (PEPB), was used as the assessment model. Two questionnaire surveys were conducted to extract the necessary information for analyzing user's behavior intention in two different regions. Taiwan and Indonesia were selected as case studies of developed and developing regions, respectively. Structural Equation Modeling (SEM) was used to analyze the proposed model and the result reveals that the model explains $49 \%$ of behavior intention to use ecolabel product in Taiwan's case and 72\% in Indonesia's case. The findings revealed that attitude (AT) is the key factor to determine the behavioral intention (BI) in both Taiwan and Indonesia. Several practical recommendations based on the finding can be considered as input for the governments and related agencies to persuade manufacturing companies to produce more ecolabel products. Increased citizens' intention to use ecolabel products help the company to reach broader target market and provide incentives to manufacturing companies to produce more environmentally friendly products.
\end{abstract}

Keywords: ecolabel product; behavior intention; citizens; Indonesia; Taiwan

\section{Introduction}

Eco-friendly products consist of safe materials and non-toxic ingredients that can be reused and have no negative effect on the ecology or the environment during production, manufacture, installation, and post usage [1]. Companies are motivated to produce the eco-friendly product because of the arising global environmental issues in recent decades. Many business processes produce pollutants and consume natural resources. This situation is pernicious and damaging to the earth [2]. Eco-products 
usually have an identifying label. This label shows that the products were made with respect to the environmental sustainability aspects. This label helps consumers to recognize the environmentally friendly products [3]. The concept of ecolabel program was firstly initiated by Germany in 1977 [4], followed by Canada, Japan, Nordic regions (Sweden, Norway, Finland, Denmark, and Iceland), the United States, New Zealand, Austria, and, more recently, China, India, Thailand, Africa, and Indonesia $[5,6]$.

Research created environmentally friendly products as an attempt to solve environmental problems. Some studies about waste treatment technology $[7,8]$, recycling technology $[9,10]$, or alternatives to non-renewable raw materials $[1,11]$ involved environmentally friendly products. It is critical for consumers to recognize the environmentally friendly product using ecolabel. Thus, they will be able to participate in the attempt to support the environment. In particular, this research utilized the behavioral theory for analysis.

The theory of planned behavior (TPB) is a widely used theory to predict intention and behavior over the past twenty years [12]. TPB has been applied to study environmentally friendly behavior across countries. Gao et al. [13] studied 26 articles of hospitality journals to identify the relationship of consumers' perceptions and their green behaviors. They found that there is strong positive correlation between both factors. Scalco et al. [14] reviewed 23 different studies that applied the TPB to identify the sustainable purchase of consumer towards the organic food. They concluded that the attitude of the individual has the most critical influence to shape the buying intention. Lanzini and Khan [15] reviewed 58 primary studies to identify the relevant predictor on the consumer preference on cars or other alternative environmentally-friendly mode of transport. They found that there is a relevant role of environmental variable to shape the intention toward the behavior of choosing the travel mode. The previously mentioned studies proved that TPB is applicable to identify the consumers' intention to use the green products.

Meike and Grinstein [16] reviewed 66 articles from 28 countries about the application of TPB in studying the environmental behavior. They found that developed countries have more tendency for the intention to behave environmentally and to materialize the actual behavior, compared to the less developed countries. Mancha and Yoder [17] used bi-national sample to evaluate the environmental TPB. They suggested the cultural affluence as important consideration in environmental TPB. Moreover, according to Rahbar and Wahid [18], the cultural difference influences the consumer understanding of the ecolabel product. Culture is a critical factor that determines people behavior $[19,20]$. Previously mentioned studies motivated this present study to use two different regions (developed region and developing region) as the study object to further compare the model result of those two regions. This was the first attempt to investigate the use of ecolabel for citizens' behavior intention in developed and developing regions using Pro Environmental Planned Behavior (PEPB) model. PEPB is a model developed by Persada [21], originated from Theory of Planned Behavior (TPB). This research was also a continuation of the research by Nadlifatin et al. [22], which suggested to explore more on the behavior intention of ecolabel usage with different model as well as to explore a developed region.

Two regions were investigated as the case studies: Taiwan and Indonesia. As a developing region, Indonesia sent many of their workers to Taiwan as developing region. This relation makes the research on both regions quite interesting. Furthermore, the importance of cultural consideration in identifying the consumer behavior [18-20] strengthen the criticality of the comparison study between Taiwan and Indonesia on the consumer behavioral intention to use an ecolabel product. The comparison between both regions on the consumer behavioral intention to use the ecolabel product helps both regions conduct cross evaluation towards each other. Thus, they can create more sustained and better cooperation though the ecolabel program to support the environment.

The outcomes of this research are expected to lead to the assessment of the ecolabel from both regions' consumers point of view and to propose some recommendations to attract consumers to use ecolabel products. Increasing the citizen intention to use ecolabel products is beneficial to increase 
the target market. It motivates the manufacturers to develop more eco-friendly products to support the environment.

The structure of this article is arranged as follows. Section 2 explains the theoretical PEPB model, and the ecolabel programs in Taiwan and Indonesia. Several hypotheses are made in this section. Section 3 describes the research methodology, including how the data were gathered and analyzed. Section 4 covers the data analysis, result, and discussion. Section 5 concludes the study with some recommendations and limitations for further research consideration.

\section{Theoretical Framework}

\subsection{Ecolabel Program in Taiwan and Indonesia}

Green Mark ecolabel is a program introduced by the Environmental Protection Administration (EPA) of Taiwan to support the environmental protection. In the manufacturing industry sectors, the Green Mark ecolabel is intended to distinguish producers who apply green processes [23]. Logotype of the Green Mark printed on product label helps consumers to recognize companies that apply green manufacturing processes [24]. Green Mark certification is projected based on eco-friendly principle of International Organization for Standardization (ISO) 14024 [25].

Aligning to government environmental regulations, environmental labeling or ecolabel programs are widely practiced in several developing nations including Indonesia [26]. The logo of the "Ekolabel" is a pro-environmental program created by Indonesian government, which is targeted to companies to certify their products with the ecolabel to support the environmental awareness [6]. Figure 1 showed the Indonesian ecolabel logo. Indonesia has lower implementation on the ecolabel program compared to other Asian countries.
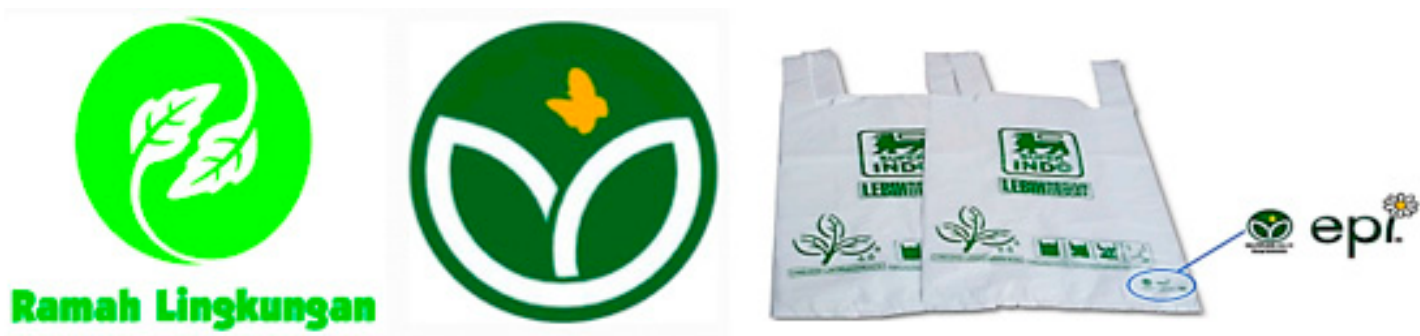

Figure 1. Ekolabel Logo: Type 1 (Left); Type 2 (Middle); and the logo on Product (Right) [27-29].

\subsection{The Ecolabel Effectiveness and the Studies on Intention to Use Ecolabel Products in Taiwan and Indonesia}

Researchers have identified the effectiveness of ecolabel. The ecolabel increases the consumer awareness towards the environmental issue [30]. Although quantifying the effect of ecolabel is difficult, in the longer term, it has enormous benefit associated with better informed consumers that lead to more demand for more effective environmental legislation [30]. Ecolabel is one of the more high-profile market-based tools to achieve environmental objective [31]. It increases sales by increasing the product differentiation, accountability, or consumer preference toward eco-friendly products [32]. It is indicated as an important tool to substantiate environmental product claims for the consumers [33]. Overall, the effectiveness of ecolabel was proven as a guiding instrument for consumers to choose the eco-friendly products [34]. Those reasons bring the criticality of studies on the consumer behavioral intention to use the ecolabel product.

Some researchers studied the intention to use the ecolabel product in Indonesia and Taiwan, from either manufacturer or consumer point of view. Lin et al. [23] was the first to study initial intention to apply green mark ecolabel in Taiwan from manufacturer point of view. The result indicated that document verification stage for the ecolabel application needs to be improved to motivate manufacturers to apply the ecolabel for their products. Meanwhile, research on intention to use the ecolabel in Indonesia from the manufacturer point of view was first studied by Razif and Persada [6]. 
They studied the utilization of the environmental impact assessment (EIA) framework for Ecolabel certification initiative. They found that the EIA framework could detect the environmental impacts on the manufacturing process. On the other hand, from the consumer point of view, nadlifatin et al. [22] measured the citizens' behavior intention in using the ecolabel products in Indonesia. They found that the company management and the policy maker should increase their effort to increase citizen's intention to use the ecolabel product. Accordingly, there is no study that investigates the intention to use the ecolabel product in Taiwan based on the consumer point of view. This research intended to study intention to use the ecolabel product in Taiwan and Indonesia based on the consumers point of view.

According to the previous review, study on intentions to use ecofriendly products and label have some theoretical and practical implications. Theoretically, it highlights the literature that the ecolabel is critical to be applied to the eco-friendly products. Practically, it helps to increase the effectivity of the ecolabel, from either consumer or manufacturer perspective. It helps identify the factors that motivate consumers to use the ecolabel products. It helps identify the factors that motivate manufacturers to apply the ecolabel to their products. In this study, some recommendations can be proposed to improve the ecolabel system to help increasing the ecolabel effectiveness for both manufacturer and consumer.

\subsection{Theory of Planned Behavior (TPB) and Theory of Pro Environmental Planned Behavior Model (PEPB)}

The Theory of Planned Behavior (TPB) is a "a theory designed to predict and explain human behavior in specific contexts" [35]. The TPB model consists of two parts. The first part of TPB is the part that predicts behavior. This first part includes two latent variables: intention and perceived behavioral control. The intention as central factor of TPB is the motivation, an effort of individual to perform the behavior if they control whether to perform or not to perform the behavior. The perceived behavioral control is the perception of the ease or difficulty of performing the behavior of interest. Both the intention and perceived behavioral control can directly predict behavioral achievement positively. The second part of TPB is the part that predicts intention. This part includes three latent variables: attitude, subjective norms, and perceived behavioral control. The attitude is the degree to which a person has a favorable or unfavorable evaluation or appraisal of the behavior in question. The subjective norms are the perceived social pressure to perform or not to perform the behavior. The perceived behavioral control is the perceived ease or difficulty of performing the behavior and it is assumed to reflect past experience as well as anticipated impediments and obstacles. Attitude, subjective norms, and perceived behavioral control positively predict the intention.

According to Conner [36], it is critical to extend the TPB to highlight its contributions. There have been several efforts to extend the TPB to include other potentially relevant determinants of behavior, thereby increasing the predictive ability [37-41]. Some of the extended TPB related to the environmental domain and aimed to support the environment sustainability [42-44]. This study used the extended TPB called PEPB. PEPB is the continuation of the TPB model [21,27,45-47]. TPB only considers individual perceptions of contextual factors, as relatively expressed in perceived behavioral control. Meanwhile, the PEPB adds two factors: Perceived Authority Support (PAS) and Perceived Environmental Concern (PEC). This model was proposed by Persada [21] to predict the process of Environmental Impact Assessment (EIA). Adding these two factors to TPB formed PEPB (Figure 2). By using PEPB model, this study examines factors that influence the citizens' behavior intention on ecolabel product usage. The proposed model, as illustrated in Figure 3, shows that there are six factors: Perceived Authority Support (PAS), Perceived Environmental Concern (PEC), Attitude (AT), Subjective Norms (SN), Perceived Behavior Control (PBC), and Behavior Intention (BI). 


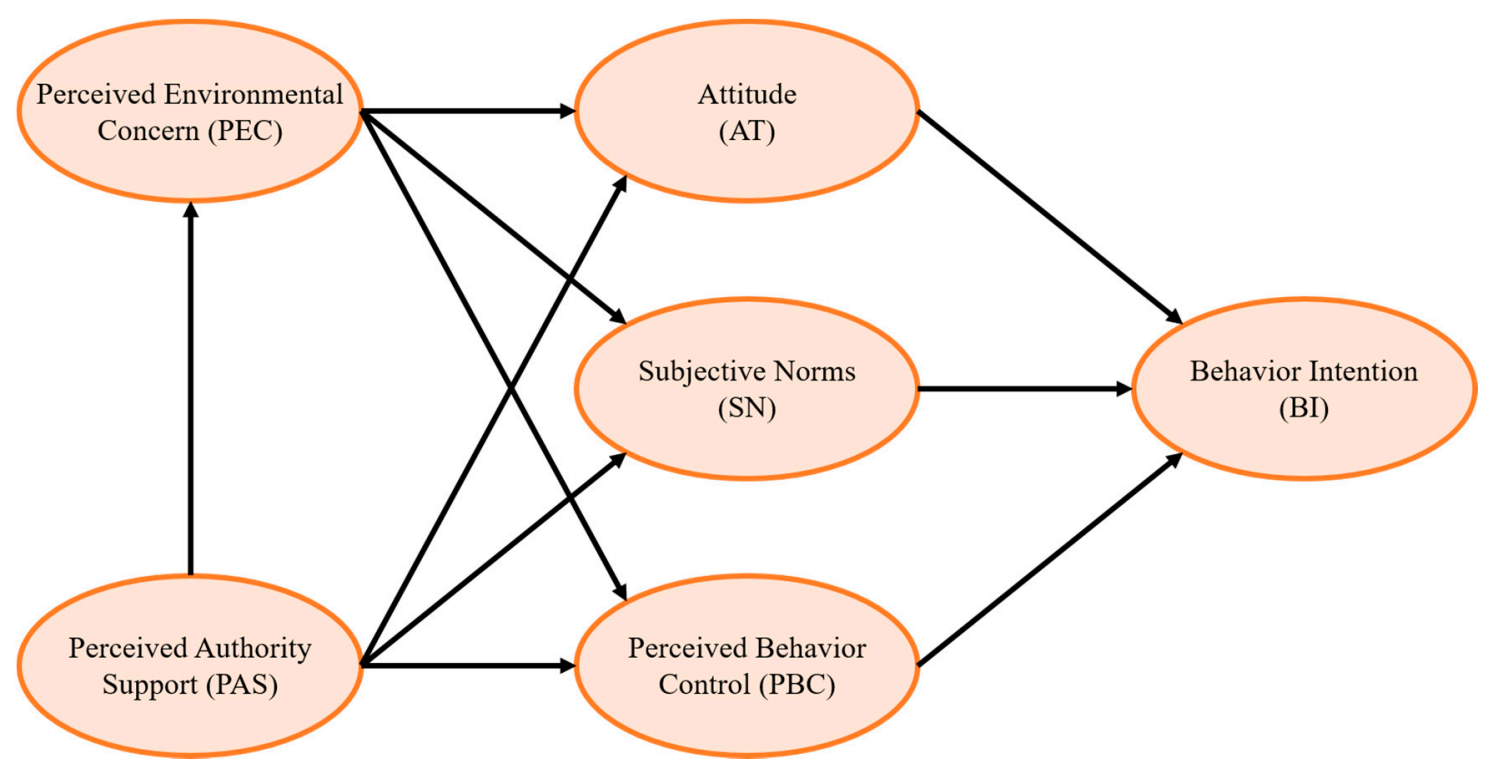

Figure 2. Pro-environmental Planned Behavior (PEPB) Model.

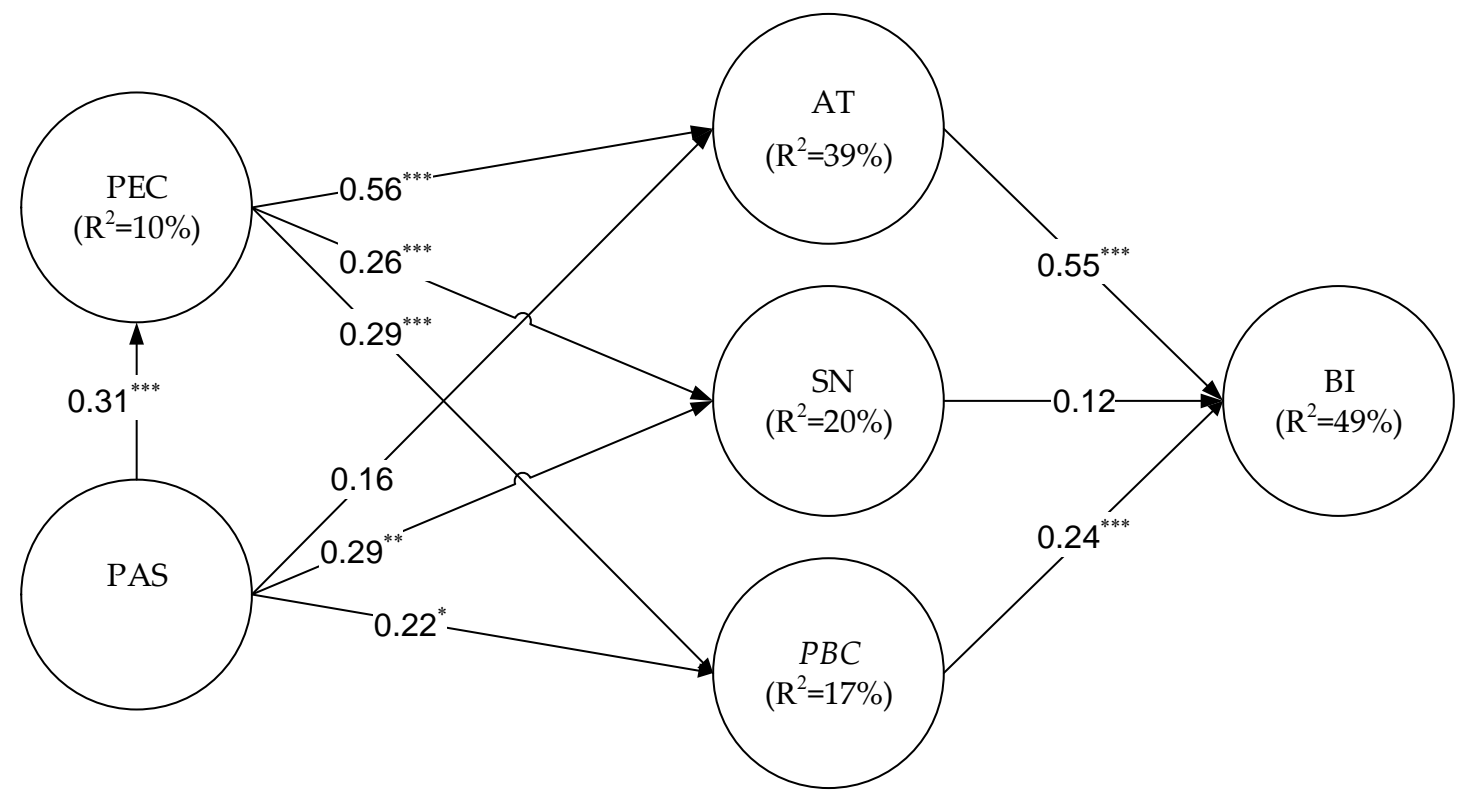

Figure 3. PEPB Model Result for Taiwan Case. Note: ${ }^{* *} p \leq 0.01,{ }^{* *} p \leq 0.05$, and ${ }^{*} p \leq 0.1$.

\subsubsection{Perceived Authority Support}

PAS can be seen as an individual's perception about regulations, resources, facilities and support provided by the agency or by the government authority that can help individuals conduct a particular behavior [21,27]. In this study, the authority holder is the government that created the regulation for the ecolabel program. The government effort to lead the ecolabel program is expected to influence the consumers preference towards the ecolabel products. If the government conducts the ecolabel program perfectly, consumers will be more motivated to use the ecolabel product. The PAS was proven to positively influence the AT, SN, PBC, and PEC for environmental impact assessment participation [21] and green skincare purchasing behavior [48]. Thus, this study proposed that the PAS positively influences the $\mathrm{AT}, \mathrm{SN}$, and $\mathrm{PBC}$ in the ecolabel product usage. 


\subsubsection{Perceived Environmental Concern}

Perceived environmental concern (PEC) can be seen as individual perception assessment against environmental consequences [21,49]. In this study, the PEC is the feeling of the consumers towards the ecolabel product. What consumers feels when using the ecolabel product was expected to influence the preference towards the ecolabel products. If the consumers feel that it is good to use the ecolabel products, they will definitely use it. The PEC was proven to positively influence the AT, SN, and PBC for environmental impact assessment participation [21] and green skincare purchasing behavior [48]. Thus, this study proposed that PEC positively influences the AT, SN, and PBC in the ecolabel product usage.

\subsubsection{Attitude}

Attitude (AT) toward behavior is defined as a person's overall favorable perception toward the behavior [21,50]. In this study, the AT is the favorable perception of consumers of using the ecolabel product. What consumers perceive of using ecolabel product was expected to influence the consumers preference on that product. If the consumers have good perception to use the ecolabel product, they will definitely use the ecolabel product. The AT was proven to positively influence the SN for environmental impact assessment participation [21] and green skincare purchasing behavior [48]. Thus, this study proposed that AT positively influence the BI in the ecolabel product usage.

\subsubsection{Perceived Behavioral Concern}

Perceived Behavioral Concern (PBC) refers to the perception of the people about their control ability to perform a particular behavior [51-53]. In this study, PBC is the perception of the consumers ability to control the usage of the ecolabel product. What consumers perceived about their control to use the ecolabel product was expected to influence their intention to use the product. If the consumers perceive the good control in using the ecolabel products, they will use the ecolabel products. The BPC was proven to positively influence the BI for environmental impact assessment participation [21] and green skincare purchasing behavior [48]. Thus, this study proposed that PBC positively influences the $\mathrm{BI}$ in the ecolabel product usage.

\subsubsection{Subjective Norms}

Subjective Norms is "the perceived social pressure to perform or not perform a behavior" [35]. In this study, the $\mathrm{SN}$ is the social pressure felt by the consumers to use the ecolabel product. The social pressure was expected to influence the consumers preference to use the ecolabel product. If there is great support from the society to use the ecolabel product, the consumers will use the ecolabel products. The $\mathrm{SN}$ was proven to positively influence the $\mathrm{BI}$ for environmental impact assessment participation [21] and green skincare purchasing behavior [48]. Thus, this study proposed that SN positively influences the $\mathrm{BI}$ in the ecolabel product usage.

\subsubsection{Behavior Intention}

Behavioral Intention (BI) is defined as the possibility that a person's perceived or "subjective likelihood that he or she will engage in a certain behavior" [54]. In this study, the BI is the intention of the consumers to use the ecolabel product. TPB postulates that the behavior forecasted by the intention is predicted by three social-cognitive factors: AT, $\mathrm{SN}$, and PBC. As the Squared Multiple Correlation (SMC) of these factors would explain the overall contribution of the models against the actual condition, no hypothesis has been proposed for BI factor.

This research classified six factors and 20 hypotheses (Table 1) stated for two regions (ten hypotheses for each region). In this study, the six factors mentioned in the model were examined as to whether they have significant influences towards citizens' behavior intentions to use ecolabel products. If the hypotheses testing showed positive results, it meant the concerned factors affect citizens' behavior intentions in ecolabel product usage. 
Table 1. Derivation of hypotheses for Taiwan and Indonesia Case.

\begin{tabular}{cl}
\hline No & \multicolumn{1}{c}{ Hypothesis } \\
\hline 1 & $\begin{array}{l}\text { Perceived Authority Support (PAS) is positively related to Perceived Environmental Concern (PEC) of } \\
\text { citizens' intention to use ecolabel product }\end{array}$ \\
\hline 2 & $\begin{array}{l}\text { Perceived Authority Support (PAS) is positively related to Attitude (AT) of citizens' intention to use } \\
\text { ecolabel product }\end{array}$ \\
\hline 3 & $\begin{array}{l}\text { Perceived Authority Support (PAS) is positively related to Subjective Norms (SN) of citizens' intention } \\
\text { to use ecolabel product }\end{array}$ \\
\hline 4 & $\begin{array}{l}\text { Perceived Authority Support (PAS) is positively related to Perceived Behavior Control (PBC) of citizens' } \\
\text { intention to use ecolabel product }\end{array}$ \\
\hline 5 & $\begin{array}{l}\text { Perceived Environmental Concern (PEC) is positively related to Attitude (AT) of citizens' intention to } \\
\text { use ecolabel product }\end{array}$ \\
\hline 6 & $\begin{array}{l}\text { Perceived Environmental Concern (PEC) is positively related to Subjective Norms (SN) of citizens' } \\
\text { intention to use ecolabel product }\end{array}$ \\
\hline 7 & $\begin{array}{l}\text { Perceived Environmental Concern (PEC) is positively related to Perceived Behavior Control (PBC) of } \\
\text { citizens' intention to use ecolabel product }\end{array}$ \\
\hline 8 & Attitude (AT) is positively related to Behavior Intention (BI) of citizens' intention to use ecolabel product \\
\hline 9 & $\begin{array}{l}\text { Subjective Norms (SN) is positively related to Behavior Intention (BI) of citizens' intention to use } \\
\text { ecolabel product }\end{array}$ \\
\hline 10 & $\begin{array}{l}\text { Perceived Behavior Control (PBC) is positively related to Behavior Intention (BI) of citizens' intention to } \\
\text { use ecolabel product }\end{array}$ \\
\hline
\end{tabular}

\section{Methodology}

The design of this research was the Confirmatory Factor Analysis (CFA) to justify the correlation in PEPB model. The covariance-based (CB) Structural Equation modeling was conducted using AMOS (Analysis of Moment Structure) software [55]. In CFA, a model that has been developed based on theory or the findings of the past can be tested against empirical data [56]. The correlation proposed in this study was based on six factors: PAS, PEC, AT, SN, PBC, and BI. In the model, BI is a representation as well as target of analysis to understand the characteristics of intention in ecolabel product usage. The questionnaire contained two parts. In the first part, 18 questions were prepared, where three questions were designed for each factor (Table 2). The questions used a five-point Likert scale, ranging from "I strongly disagree" to "I strongly agree". The second part of the questionnaire consisted of background information such as age and gender. Online and paper-based questionnaires were used to collect the data. The questionnaire was distributed over twelve months, from January to December 2016. The sampling methods used was the non-probability sampling, specifically the purposive sampling and the convenience sampling, by determining the specific sample on the basis of relevance (the full right contribute as citizen) and the first to hand respondent during the time span [57]. The citizens of Indonesia, which have a minimum age of 17, were targeted as a respondent. This age is considered by the law and the constitution as citizens who have full rights to aspirate and contribute to legal action. To compare using the same conditions, we also applied this minimum age to respondents in Taiwan. SPSS and AMOS 20 were utilized as the tool for analysis.

\section{Analysis Result}

\subsection{Data Analysis}

Our questionnaire was distributed from January to December 2016. During the time, 172 questionnaires from Taiwan and 210 questionnaires from Indonesia were collected and used for analysis. An illustration representing the respondent demographic percentages is shown in Table 3. 
Table 3 illustrates the working status, the range of age, and the gender of the respondents in Taiwan and Indonesia. The majority of respondents were non-working. In terms of their age, most respondents were 20-30 years old. Most respondent from Taiwan were male (55 percent). On the other hand, most respondent from Indonesia were females (62 percent). The data from Taiwanese questionnaires have an average range of 3.113-4.121, which is the range of neutral answer to agreement answer. On the other hand, the data from Indonesian questionnaires have an average range of 2.995-4.252. It reveals that respondents agree about the importance of seven factors in ecolabel product usage. Respondent's descriptive and reliability statistics are shown in Table 4.

Table 2. Questionnaire design.

\begin{tabular}{|c|c|c|}
\hline Variable & Question & $\begin{array}{c}\text { Adapted } \\
\text { Source }\end{array}$ \\
\hline PAS1 & Government enacts regulations to allow me as citizen to use the ecolabel products & {$[21,22,27]$} \\
\hline PAS2 & $\begin{array}{l}\text { The government of Indonesia is active in setting up the facilities that allow me to use the } \\
\text { ecolabel products }\end{array}$ & {$[21,22,27]$} \\
\hline PAS3 & The government of Indonesia encourages me to use the ecolabel products & {$[21,22,27]$} \\
\hline PEC1 & $\begin{array}{l}\text { I am very worried about the state of the world environment and what that will mean for } \\
\text { my future so I need to keep the environment by using the ecolabel products }\end{array}$ & {$[21,22,27]$} \\
\hline PEC2 & $\begin{array}{l}\text { Humans are very often misusing/damaging the environment, so it is necessary for me to } \\
\text { help save the environment by using the ecolabel products }\end{array}$ & {$[21,22,27]$} \\
\hline PEC3 & $\begin{array}{l}\text { When humans interfere with nature, nature produces disastrous consequences so I need to } \\
\text { participate by using the ecolabel products to avoid/reduce the disruption of nature }\end{array}$ & {$[21,22,27]$} \\
\hline AT1 & For me, the use of ecolabel products is very good & {$[21,50]$} \\
\hline AT2 & For me, the use of ecolabel products is wanted by everyone & {$[21,50]$} \\
\hline AT3 & For me, the use of ecolabel products is loved by everyone & {$[21,50]$} \\
\hline SN1 & Most of the people who are important to me think I have to use the ecolabel products & {$[21,50]$} \\
\hline SN2 & Most of the people who are important to me want me to use the ecolabel products & {$[21,50]$} \\
\hline SN3 & Most of the people who are pretty important to me prefer me to use the ecolabel products & {$[21,50]$} \\
\hline PBC1 & I have the knowledge and the time to use the ecolabel products & {$[21,50]$} \\
\hline PBC2 & I had the opportunity to use the ecolabel products & {$[21,50]$} \\
\hline PBC3 & I was defining my desire to use the ecolabel products & {$[21,50]$} \\
\hline BI1 & I am willing to use the ecolabel products & {$[21,50]$} \\
\hline BI2 & I plan to use the ecolabel products & {$[21,50]$} \\
\hline BI3 & I will try to use the ecolabel products & {$[21,50]$} \\
\hline
\end{tabular}

Table 3. Respondent's Demographic.

\begin{tabular}{cccc}
\hline Regions & & Taiwan & Indonesia \\
\hline Respondent Demographic & & \multicolumn{2}{c}{ In Percent (\%) } \\
\hline \multirow{2}{*}{ Working Status } & Working & 10 & 16 \\
& Not Working & 90 & 84 \\
\hline \multirow{2}{*}{ Range of Age } & $<20$ years old & 18 & 15 \\
& 20-30 years old & 81 & 82 \\
& $>30$ years old & 1 & 3 \\
\hline \multirow{2}{*}{ Gender } & Female & 45 & 62 \\
& Male & 55 & 38 \\
\hline
\end{tabular}

The foremost step that must be performed prior to Structural Equation Modeling (SEM) is a reliability analysis. In the analysis about the behavioral model, Cronbach's $\alpha$ is the most widely used index of the internal consistency reliability of a set of scale or test items [58-60]. Meanwhile, to analyze 
the reliability and convergent validity, Factor Loading (FL), Composite Reliability (CR) $[61,62]$ and Average Variance Extracted (AVE) [63] were used. Factor loadings are a way to understand the role of each item in defining a factor [64]. CR is a measure of the overall reliability of a collection of items that form the latent variables by considering factor loading perspective [62]. AVE measures the degree of variance captured by construct or versus the level due to measurement error. For Factor Loading, CR, and Cronbach's $\alpha$, a value above 0.7 is acceptable [65-68]. For AVE, a value above 0.7 is considered very good, whereas the value of 0.5 is acceptable [69] (Table 4 ).

Table 4. Respondent's descriptive and reliability statistics.

\begin{tabular}{|c|c|c|c|c|c|c|c|c|c|c|c|c|c|}
\hline \multirow[b]{2}{*}{ Factor } & \multirow[b]{2}{*}{ Item } & \multicolumn{6}{|c|}{ Taiwanese Data } & \multicolumn{6}{|c|}{ Indonesian Data } \\
\hline & & Mean & SD & $\begin{array}{c}\text { FL } \\
(\geq 0.7)\end{array}$ & $\begin{array}{c}\alpha \\
(\geq 0.7)\end{array}$ & $\begin{array}{c}\text { CR } \\
(\geq 0.7)\end{array}$ & $\begin{array}{c}\text { AVE } \\
(\geq 0.5)\end{array}$ & Mean & SD & $\begin{array}{c}\text { FL } \\
(\geq 0.7)\end{array}$ & $\begin{array}{c}\alpha \\
(\geq 0.7)\end{array}$ & $\begin{array}{c}\text { CR } \\
(\geq 0.7)\end{array}$ & $\begin{array}{c}\text { AVE } \\
(\geq 0.5)\end{array}$ \\
\hline \multirow{3}{*}{ PAS } & PAS1 & 3.723 & 0.829 & 0.74 & \multirow{3}{*}{0.833} & \multirow{3}{*}{0.833} & \multirow{3}{*}{0.625} & 3.633 & 0.995 & 0.79 & \multirow{3}{*}{0.749} & \multirow{3}{*}{0.750} & \multirow{3}{*}{0.600} \\
\hline & PAS2 & 3.454 & 0.982 & 0.81 & & & & 3.200 & 1.119 & 0.76 & & & \\
\hline & PAS3 & 3.582 & 0.919 & 0.82 & & & & - & - & - & & & \\
\hline \multirow{3}{*}{ PEC } & PEC1 & 3.816 & 0.825 & 0.81 & \multirow{3}{*}{0.888} & \multirow{3}{*}{0.889} & \multirow{3}{*}{0.729} & 4.252 & 0.911 & 0.87 & \multirow{3}{*}{0.897} & \multirow{3}{*}{0.898} & \multirow{3}{*}{0.747} \\
\hline & PEC2 & 3.922 & 0.802 & 0.89 & & & & 4.229 & 0.804 & 0.91 & & & \\
\hline & PEC3 & 3.908 & 0.853 & 0.86 & & & & 4.152 & 0.883 & 0.81 & & & \\
\hline \multirow{3}{*}{ AT } & AT1 & 3.638 & 0.864 & 0.78 & \multirow{3}{*}{0.820} & \multirow{3}{*}{0.820} & \multirow{3}{*}{0.603} & 4.214 & 0.884 & 0.76 & \multirow{3}{*}{0.879} & \multirow{3}{*}{0.879} & \multirow{3}{*}{0.708} \\
\hline & AT2 & 4.035 & 0.805 & 0.78 & & & & 3.914 & 0.903 & 0.89 & & & \\
\hline & AT3 & 3.716 & 0.889 & 0.77 & & & & 3.795 & 0.902 & 0.87 & & & \\
\hline \multirow{3}{*}{ SN } & SN1 & 3.121 & 0.832 & 0.84 & \multirow{3}{*}{0.917} & \multirow{3}{*}{0.920} & \multirow{3}{*}{0.794} & 3.419 & 1.000 & 0.82 & \multirow{3}{*}{0.892} & \multirow{3}{*}{0.895} & \multirow{3}{*}{0.741} \\
\hline & SN2 & 3.113 & 0.863 & 0.95 & & & & 3.329 & 0.964 & 0.92 & & & \\
\hline & SN3 & 3.184 & 0.859 & 0.88 & & & & 3.462 & 0.974 & 0.84 & & & \\
\hline \multirow{2}{*}{$\mathrm{PBC}$} & PBC1 & 3.858 & 0.789 & 0.71 & & & & 3.690 & 0.899 & 0.73 & & & \\
\hline & PBC2 & 3.830 & 0.801 & 0.89 & 0.784 & 0.784 & 0.648 & 3.838 & 0.914 & 0.84 & 0.763 & 0.763 & 0.619 \\
\hline & BI1 & 4.121 & 0.788 & 0.79 & & & & 4.162 & 0.854 & 0.86 & & & \\
\hline BI & BI2 & 3.532 & 0.816 & 0.70 & 0.811 & 0.818 & 0.601 & 4.010 & 0.897 & 0.86 & 0.915 & 0.914 & 0.780 \\
\hline & BI3 & 4.014 & 0.717 & 0.83 & & & & 3.986 & 0.910 & 0.91 & & & \\
\hline
\end{tabular}

SEM was performed to test the proposed hypotheses with AMOS 20, and the results are presented in Figures 3 and 4. Twenty correlation lines are determined for both regions based on the proposed hypotheses. The results of the validation of the hypotheses are shown in Table 5.

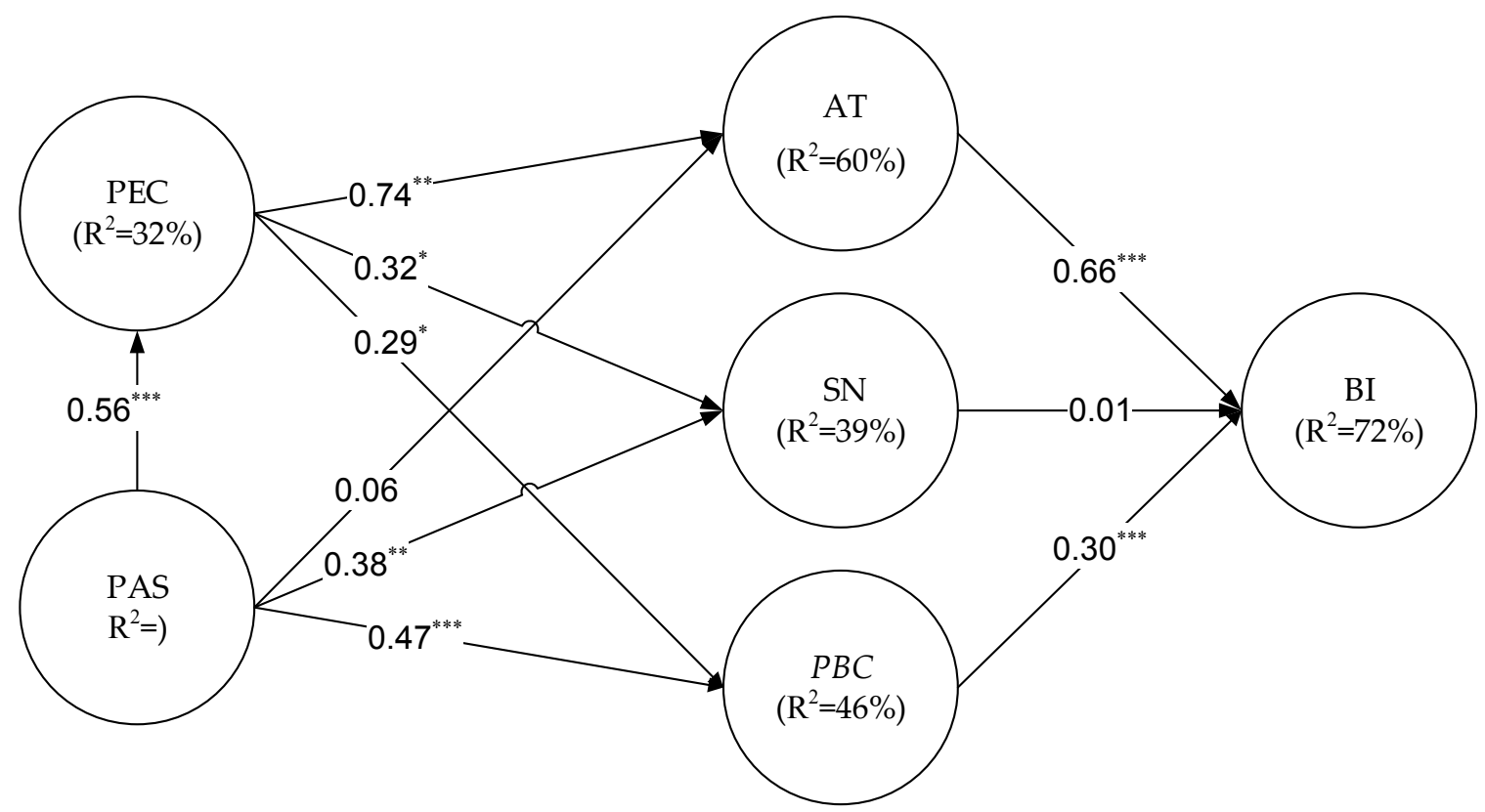

Figure 4. PEPB Model Result for Indonesia Case. Note: ${ }^{* *} p \leq 0.01,{ }^{* *} p \leq 0.05$, and ${ }^{*} p \leq 0.1$. 
Table 5. Respondent's Hypothesis Test.

\begin{tabular}{cccccc}
\hline & Taiwan & & & Indonesia & \\
\hline Hypothesis & Result & Significance & Hypothesis & Result & Significance \\
\hline $\mathrm{H}_{1}:$ PEC $\leftarrow$ PAS & Positive & Accepted & $\mathrm{H}_{11}:$ PEC $\leftarrow$ PAS & Positive & Accepted \\
$\mathrm{H}_{2}: \mathrm{AT} \leftarrow$ PAS & Positive & Rejected & $\mathrm{H}_{12}: \mathrm{AT} \leftarrow$ PAS & Positive & Rejected \\
$\mathrm{H}_{3}: \mathrm{SN} \leftarrow$ PAS & Positive & Accepted & $\mathrm{H}_{13}: \mathrm{SN} \leftarrow$ PAS & Positive & Accepted \\
$\mathrm{H}_{4}: \mathrm{PBC} \leftarrow$ PAS & Positive & Accepted & $\mathrm{H}_{14}:$ PBC $\leftarrow$ PAS & Positive & Accepted \\
$\mathrm{H}_{5}: \mathrm{AT} \leftarrow \mathrm{PEC}$ & Positive & Accepted & $\mathrm{H}_{15}: \mathrm{AT} \leftarrow \mathrm{PEC}$ & Positive & Accepted \\
$\mathrm{H}_{6}: \mathrm{SN} \leftarrow \mathrm{PEC}$ & Positive & Accepted & $\mathrm{H}_{16}: \mathrm{SN} \leftarrow \mathrm{PEC}$ & Positive & Accepted \\
$\mathrm{H}_{7}: \mathrm{PBC} \leftarrow \mathrm{PEC}$ & Positive & Accepted & $\mathrm{H}_{17}: \mathrm{PBC} \leftarrow \mathrm{PEC}$ & Positive & Accepted \\
$\mathrm{H}_{8}: \mathrm{BI} \leftarrow \mathrm{AT}$ & Positive & Accepted & $\mathrm{H}_{18}: \mathrm{BI} \leftarrow \mathrm{AT}$ & Positive & Accepted \\
$\mathrm{H}_{9}: \mathrm{BI} \leftarrow \mathrm{SN}$ & Positive & Rejected & $\mathrm{H}_{19}: \mathrm{BI} \leftarrow \mathrm{SN}$ & Positive & Rejected \\
$\mathrm{H}_{10}: \mathrm{BI} \leftarrow \mathrm{PBC}$ & Positive & Accepted & $\mathrm{H}_{20}: \mathrm{BI} \leftarrow \mathrm{PBC}$ & Positive & Accepted \\
\hline
\end{tabular}

In Table 5, we can see that our hypotheses were proven to have positive path correlations. Based on Figure 3 (Taiwan) and Figure 4 (Indonesia), the key determinant factor is given to AT because it has the highest direct correlation value towards BI. To know the significant correlation between each factor, direct significance measurements were performed.

Table 5 shows that sixteen hypotheses have been proven to have positive and significant path correlation. The table also shows that there are four insignificant correlation factors. The significance correlation indicates that our proposed model is robust [70] and has appropriate inter correlation within each factor. To prove the validity of our proposed conceptual model, we performed a model fit analysis. The model fit is an assessment based on several parameters to assess that the model is strong. In this study, the fit model used refers to Hair et al. [71] consisting of the $X^{2}$ value and the associated df; one absolute fit index (i.e., GFI, RMSEA, or SRMR); one incremental fit index (i.e., CFI or TLI); one goodness-of-fit index (GFI, CFI, TLI, etc.); and one badness-of-fit index (RMSEA, SRMR, etc.). We performed a model fit test by following the model fit parameters from previous similar studies. All of the model fit parameters exceed the value of the minimum threshold (Table 6). These findings confirmed that the proposed model is appropriate (fit model). In our study, BI has $49 \%$ value for Taiwan case (Figure 3) and $72 \%$ for Indonesia case (Figure 4), which means that the predictors of Behavior Intention explain $49 \%$ of its variance for Taiwan case and explain $72 \%$ of its variance for Indonesia case. In other words, the error variance or unidentified factors is approximately $51 \%$ for Taiwan and $28 \%$ for Indonesia case.

Table 6. Model Fit Result.

\begin{tabular}{ccccccc}
\hline \multirow{2}{*}{ Model Fit Parameters } & \multicolumn{2}{c}{ Value } & \multirow{2}{*}{ Threshold } & Accepted & Rejected \\
\cline { 3 - 4 } & & Taiwan & Indonesia & & & \\
\hline 1 & $X^{2} / d f$ & 1.71 & 2.40 & $n \leq 3$ & $\sqrt{ }$ & - \\
2 & Goodness of Fit (GFI) & 0.89 & 0.88 & $n>0.80$ & $\sqrt{ }$ & - \\
3 & Comparative Fit Index (CFI) & 0.95 & 0.94 & $n \geq 0.90$ & $\sqrt{ }$ & - \\
4 & Tucker Lewis Index (TLI) & 0.93 & 0.93 & $n>0.90$ & $\sqrt{ }$ & - \\
5 & Root Mean Square Error (RMSEA) & 0.06 & 0.08 & $n \leq 0.08$ & $\sqrt{ }$ & - \\
\hline
\end{tabular}

\subsection{Discussion}

The results of this research show that the Pro-Environmental Planned Behavior (PEPB) model validates most of the proposed positive correlation, except the correlation between PAS (Taiwan) and AT (Taiwan); SN (Taiwan) and BI (Taiwan); PAS (Indonesia) and AT (Indonesia); and SN (Indonesia) to BI (Indonesia). Sixteen of twenty correlations have positive and significant values.

The first correlation between PAS and PEC $(\beta P A S(T) \rightarrow$ PEC $=0.312)$ and $(\beta P A S(I) \rightarrow$ PEC $=$ $0.562)$ describes the degree of authority and related agencies role in affecting citizens' environmental 
concern. Both Taiwanese and Indonesian authorities realize that it is important to encourage citizens' environmental concern. Consequently, both Taiwanese and Indonesian citizens perceived support from the authority. The result of Taiwan case shows medium influence given by the government, while Indonesia shows strong influence. For Taiwan case, because Taiwan has been adopting the ecolabel concept for more two decades, many companies change their product into ecofriendly products. Therefore, supports such as subsidy or reward are used by many companies, which reduced the proportion for each company and it affect the total production cost that is charged to customer. The customer consequently does not get much benefit from it. This situation can be seen as the challenge for Taiwan authority support to develop a proper strategy to ensure citizens get more benefit. For Indonesia case, since the implementation of ecolabel product is less than a decade old, the application is relatively new. Few companies use the support from the authority to their business process, and supports are used only for few manufacturing companies. The manufacturing companies, who made the ecofriendly product, charge a little because of the support from the authority holder. Thus, citizens get much more benefit from the authority support.

The next correlation is between PAS and AT $(\beta P A S(T) \rightarrow A T=0.162)$ and $(\beta P A S(I) \rightarrow A T=0.057)$. Both Taiwanese and Indonesian citizens, in this exploration study, felt that there is no significant effect. They felt that the authority support is not providing a significant contribution in this part. From PAS to $\mathrm{SN}(\beta \mathrm{PAS}(\mathrm{T}) \rightarrow \mathrm{SN}=0.292 ; \beta \mathrm{PAS}(\mathrm{I}) \rightarrow \mathrm{SN}=0.383)$ and from $\mathrm{PAS}$ to $\mathrm{PBC}(\beta \mathrm{PAS}(\mathrm{T}) \rightarrow \mathrm{PBC}=0.223$; $\beta P A S(I) \rightarrow P B C=0.475)$, the citizens get moderate influence. This condition can be seen by the policy maker to prepare some strategies that can increase positive influence of citizens AT, SN and PBC. The strategies can be informed as direct reward or appreciation to customer.

In the global world, people are perceived positively on their attitude matters from environmental concern. Thus, it can be seen in both Taiwan and Indonesia cases that they have significant correlations between PEC and AT $(\beta P E C(\mathrm{~T}) \rightarrow \mathrm{AT}=0.557 ; \beta \mathrm{PEC}(\mathrm{I}) \rightarrow \mathrm{AT}=0.742)$. This research found that there is a significant influence between PEC and SN in both Taiwan and Indonesia ( $\beta P E C(T) \rightarrow S N=0.259$; $\beta P E C(I) \rightarrow S N=0.329$ ). Many reasons can cause this situation, such as different culture and degree of education. The culture of individualism tends to affect the $\mathrm{SN}$ value. The degree of education shows a similar result. The following correlation between PEC and PBC ( $\beta$ PEC $(\mathrm{T}) \rightarrow$ PBC $=0.287$; $\beta \mathrm{PEC}(\mathrm{I}) \rightarrow \mathrm{PBC}=0.289)$ represents the degree of environmental concern between developed and developing regions.

For the next correlation, AT, SN, PBC and BI are the representation of famous Theory of Planned Behavior (TPB) factor. Many researchers show positive and significant correlations among these factors $(\beta \mathrm{AT}(\mathrm{T}) \rightarrow \mathrm{BI}=0.554 ; \beta \mathrm{AT}(\mathrm{I}) \rightarrow \mathrm{BI}=0.664) ;(\beta \mathrm{PBC}(\mathrm{T}) \rightarrow \mathrm{BI}=0.243 ; \beta \mathrm{PBC}(\mathrm{I}) \rightarrow \mathrm{BI}=0.298)$. Surprisingly, there was an uncommon situation between $\mathrm{SN}$ and BI in this research $(\beta S \mathrm{~N}(\mathrm{~T}) \rightarrow$ $\mathrm{BI}=0.117 ; \beta S N(\mathrm{I}) \rightarrow \mathrm{BI}=0.014)$. Apparently, the people who are important to citizens did not contribute a good influence. The SN correlations were not significant. This situation can be seen as an input for policy maker in both developed and developing regions in preparing a proper strategy to encounter this issue. This study found AT as the strongest factor that influences the BI directly in both Taiwan and Indonesia $(\beta \mathrm{AT}(\mathrm{T}) \rightarrow \mathrm{BI}=0.554 ; \beta \mathrm{AT}(\mathrm{I}) \rightarrow \mathrm{BI}=0.664)$. This situation can be seen as an advantage for the policy maker in both regions. Maintaining and improving the recent strategy can help citizens get a positive perception and use the ecolabel product. Finally, this study found out that the Indonesian respondents show greater behavior intention in using the ecolabel products than Taiwanese respondents. This result is quite surprising because, based on the GDP per capita [72] Taiwan is better compared to Indonesia. However, this unexpected result was understandable. Although in developed regions the actual pro-environmental behaviors have more tendency to occur compared to less developed regions, in developing regions, the pressure to be "green" grows as the dominant force and becomes as meaningful as social norms [16]. A possible reason is because the relatively new program attracts the citizens' intention to know more about the usage of ecolabel products. Taiwan respondents, who perceived the intention to use the ecolabel products longer, may feel less excited than those who newly implemented it. Responding both strongest and weakest factors in this research 
can help the policy maker as well as the manufacturing companies to better understand the citizens of both regions.

\section{Conclusions}

The present research used PEPB model to investigate the citizens' Behavior Intention (BI) regarding the usage of ecolabel products in both developed and developing regions. The PEPB model consists of six factors namely Perceived Authority Support (PAS), Perceived Environmental Concern (PEC), Attitude (AT), Subjective Norms (SN), Perceived Behavior Control (PBC), and Behavioral Intention (BI). The result indicates that $\mathrm{AT}$ is the strongest factor and $\mathrm{SN}$ is the weakest factor that fundamentally affect the individual BI. The study suggests that maintaining and improving the current strategy can help to impose positive perception about ecolabel products to the public, resulting in increasing consumption on those products.

In summary, the present research confirmed 16 out of 20 hypotheses to have significant and positive values. The present study found that Indonesia respondents show greater behavior intention in using the ecolabel products than Taiwan respondents. Indonesia has greater behavioral intention in using the ecolabel products compared to Taiwan because, as a developing region, Indonesia has more force to go "green". This is a good chance to promote pro-environmental activity as well as encourage the use of ecolabel products. Increasing citizen's intentions to use ecolabel products will persuade policy makers and companies to manage a sustainable environment. The end goal for this situation is to minimize or eliminate the negative impacts to the environment. This study, however, has a limitation, which is the number of regions involved. Adding more regions into the equation will produce a more objective result, and this should be considered in further research. Future research should also explore the rest of the population, i.e., the $51 \%$ of Taiwanese cases and $28 \%$ of Indonesian cases, as to what factors might affect or influence their decisions.

Author Contributions: I.M. performed research, analyzed the data, wrote and revised the manuscript. B.C.J. gave approval to the research execution, manuscript writing, and manuscript submission. J.C. and Y.P.R. performed research, analyzed the data, and wrote the manuscript. S.-C.L. and S.F.P. guided the research scope, methodology and research process, and gave final review suggestions of the manuscript.

Acknowledgments: The authors would like to thank the two anonymous reviewers who provided their insight on the final versions of the manuscript. A great gratitude to Institut Teknologi Sepuluh Nopember (ITS) for the publication support. We also express the great appreciation for good collaboration between National Taiwan University of Science and Technology and ITS.

Conflicts of Interest: The authors declare no conflict of interest.

\section{References}

1. Mintie, A. Using stone and ceramic tile for a healthy building environment. Stone World, 18 November 2006.

2. Dunlap, R.E.; Jorgenson, A.K. Environmental problems. In The Wiley-Blackwell Encyclopedia of Globalization; John Wiley \& Sons, Inc.: Hoboken, NJ, USA, 2012.

3. Lin, S.-C.; Rachmaniati, Y.P.; Nadlifatin, R.; Razif, M.; Persada, S.F.; Lin, A. Understanding the consumers' perspective in accepting the ecolabel product by a structural reasoned model assessment. In Proceedings of the 17th Asia Pacific Industrial Engineering and Management Systems Conference, Taipei, Taiwan, 7-10 December 2016.

4. Browner, C.M. Guidelines for Ecological Risk Assessment; U.S. Environmental Protection Agency: Washington, DC, USA, 1998.

5. Li, L.; Geiser, K. Environmentally responsible public procurement (erpp) and its implications for integrated product policy (ipp). J. Clean. Prod. 2005, 13, 705-715. [CrossRef]

6. Razif, M.; Persada, S.F. Environmental impact assessment (eia) framework for ekolabel certification initiative in indonesia: Case study of a rattan-plywood based furniture industry. Int. J. ChemTech Res. 2016, 9, 634-643.

7. Sarkis, J.; Weinrach, J. Using data envelopment analysis to evaluate environmentally conscious waste treatment technology. J. Clean. Prod. 2001, 9, 417-427. [CrossRef] 
8. Fukumori, K.; Matsushita, M.; Okamoto, H.; Sato, N.; Suzuki, Y.; Takeuchi, K. Recycling technology of tire rubber. JSAE Rev. 2002, 23, 259-264. [CrossRef]

9. Merrild, H.; Damgaard, A.; Christensen, T.H. Life cycle assessment of waste paper management: The importance of technology data and system boundaries in assessing recycling and incineration. Resour. Conserv. Recycl. 2008, 52, 1391-1398. [CrossRef]

10. Cherubini, F.; Ulgiati, S. Crop residues as raw materials for biorefinery systems-A lca case study. Appl. Energy 2010, 87, 47-57. [CrossRef]

11. Willke, T.; Vorlop, K.-D. Industrial bioconversion of renewable resources as an alternative to conventional chemistry. Appl. Microbiol. Biotechnol. 2004, 66, 131-142. [CrossRef] [PubMed]

12. Teo, T.K.G.; Lee, C.B. Examining the Efficacy of the Theory of Planned Behavior (TPB) to Understand Pre-Service Teachers' Intention to Use Technology; Nanyang Technology University: Nanyang, Singapore, 2010.

13. Gao, Y.L.; Mattila, A.S.; Lee, S. A meta-analysis of behavioral intentions for environment-friendly initiatives in hospitality research. Int. J. Hosp. Manag. 2016, 54, 107-115. [CrossRef]

14. Scalco, A.; Noventa, S.; Sartori, R.; Ceschi, A. Predicting organic food consumption: A meta-analytic structural equation model based on the theory of planned behavior. Appetite 2017, 112, 235-248. [CrossRef] [PubMed]

15. Lanzini, P.; Khan, S.A. Shedding light on the psychological and behavioral determinants of travel mode choice: A meta-analysis. Trans. Res. Part F Traffic Psychol. Behav. 2017, 48, 13-27. [CrossRef]

16. Morren, M.; Grinstein, A. Explaining environmental behavior across borders: A meta-analysis. J. Environ. Psychol. 2016, 47, 91-106. [CrossRef]

17. Mancha, R.M.; Yoder, C.Y. Cultural antecedents of green behavioral intent: An environmental theory of planned behavior. J. Environ. Psychol. 2015, 43, 145-154. [CrossRef]

18. Rahbar, E.; Wahid, N.A. Ethno-cultural differences and consumer understanding of eco-labels: An empirical study in malaysia. J. Sustain. Dev. 2010, 3, 255. [CrossRef]

19. Järvi, J. The Behaviour of Finnish Consumers towards Eco-Labelled Products; Case: S-Group Oyj; Laurea University of Applied Sciences: Vantaa, Finland, 2010.

20. Kotler, P.; Keller, K.L. Marketing Management; Prentice Hall: Upper Saddle River, NY, USA, 2006.

21. Persada, S. Pro Environmental Planned Behavior Model to Explore the Citizens' Participation Intention in Environmental Impact Assessment: An Evidence Case in Indonesia; National Taiwan University of Science \& Technology: Taipei, Taiwan, 2016.

22. Nadlifatin, R.; Lin, S.-C.; Rachmaniati, Y.P.; Persada, S.F.; Razif, M. A pro-environmental reasoned action model for measuring citizens' intentions regarding ecolabel product usage. Sustainability 2016, 8, 1165. [CrossRef]

23. Lin, S.-C.; Persada, S.F.; Nadlifatin, R.; Tsai, H.-Y.; Chu, C.-H. Exploring the influential factors of manufacturers' initial intention in applying for the green mark ecolabel in taiwan. Int. J. Precis. Eng. Manuf. Green Technol. 2015, 2, 359-364. [CrossRef]

24. Administration, E.P. A Guide to Environmental \& Social Compliance, Textile Standards \& Legislation. Available online: https://www.textilestandards.com/standards/76-taiwan-green-mark (accessed on 9 May 2017).

25. Administration, E.P. Greenliving Information Platform. Available online: https:/ /greenliving.epa.gov.tw/ Public/Eng/GreenMark/First (accessed on 22 March 2018).

26. Hanafi, J.; Kristina, H.J.; Jobiliong, E.; Christiani, A.; Halim, A.V.; Santoso, D.; Melini, E. The prospects of managing weee in indonesia. In Glocalized Solutions for Sustainability in Manufacturing; Springer: Heidelberg, Germany, 2011; pp. 492-496.

27. Lin, S.-C.; Nadlifatin, R.; Amna, A.R.; Persada, S.F.; Razif, M. Investigating citizen behavior intention on mandatory and voluntary pro-environmental programs through a pro-environmental planned behavior model. Sustainability 2017, 9, 1289. [CrossRef]

28. Marine Environment-International Maritime Organization. Inclusion of Ecolabel Logo According to Minister of Environment Regulation Number 02/2014. Available online: http://www.menlh.go.id/ pencantuman-logo-ekolabel-sesuai-permen-022014/ (accessed on 22 March 2018). 
29. Sadikin, S.R. Public Procurement Sustainability in Indonesia: Environmental, Social or Economic Tradeoffs, 3rd ed. 2008, pp. 587-617. Available online: https://www.researchgate.net/publication/242158007_ Public_Procurement_Sustainability_In_Indonesia_Environmental_Social_Or_Economic_Tradeoffs (accessed on 22 March 2018).

30. Cadman, J.; Dolley, P. The Direct and Indirect Benefits of the European Ecolabel-A Final Report Produced for DG Environment at the European Commission; AEA Technology: Oxfordshire, UK, 2004.

31. Rotherham, T. The Trade and Environmental Effects of Ecolabels: Assessment and Response; United Nations Environment Programme: Nairobi, Kenya, 2005.

32. Horne, R.E. Limits to labels: The role of eco-labels in the assessment of product sustainability and routes to sustainable consumption. Int. J. Consum. Stud. 2009, 33, 175-182. [CrossRef]

33. LLC, U. Understanding the Effective Use of Green Product Labels. UL Environment, Inc., 2016. Available online: https://www.greenbiz.com/whitepaper/understanding-effective-use-green-productlabels (accessed on 22 March 2018).

34. Du, L.Q.N.Q. Effectiveness of Eco-Label? A Study of Swedish University Students' Choice on Ecological Food; Umeå School of Business: Umeå, Sweden, 2010.

35. Ajzen, I. The theory of planned behavior. In Organizational Behavior and Decision Processes; Academic Press Inc.: Cambridge, MA, USA, 1991.

36. Conner, M. Extending not retiring the theory of planned behaviour: A commentary on sniehotta, presseau and araújo-soares. Health Psychol. Rev. 2015, 9, 141-145. [CrossRef] [PubMed]

37. Bagot, K.L.; Masser, B.M.; White, K.M. Using an extended theory of planned behavior to predict a change in the type of blood product donated. Ann. Behav. Med. 2015, 49, 510-521. [CrossRef] [PubMed]

38. Donald, I.J.; Cooper, S.R.; Conchie, S. An extended theory of planned behaviour model of the psychological factors affecting commuters' transport mode use. J. Environ. Psychol. 2014, 40, 39-48. [CrossRef]

39. Kashif, M.; De Run, E.C. Money donations intentions among muslim donors: An extended theory of planned behavior model. Int. J. Nonprofit Volunt. Sect. Mark. 2015, 20, 84-96. [CrossRef]

40. Mullan, B.; Allom, V.; Sainsbury, K.; Monds, L.A. Examining the predictive utility of an extended theory of planned behaviour model in the context of specific individual safe food-handling. Appetite 2015, 90, 91-98. [CrossRef] [PubMed]

41. St-Pierre, R.A.; Derevensky, J.L.; Temcheff, C.E.; Gupta, R. Adolescent gambling and problem gambling: Examination of an extended theory of planned behaviour. Int. Gambl. Stud. 2015, 15, 506-525. [CrossRef]

42. Han, H.; Kim, Y. An investigation of green hotel customers' decision formation: Developing an extended model of the theory of planned behavior. Int. J. Hosp. Manag. 2010, 29, 659-668. [CrossRef]

43. Chen, M.-F.; Tung, P.-J. Developing an extended theory of planned behavior model to predict consumers' intention to visit green hotels. Int. J. Hosp. Manag. 2014, 36, 221-230. [CrossRef]

44. Rhodes, R.E.; Beauchamp, M.R.; Conner, M.; de Bruijn, G.-J.; Kaushal, N.; Latimer-Cheung, A. Prediction of depot-based specialty recycling behavior using an extended theory of planned behavior. Environ. Behav. 2015, 47, 1001-1023. [CrossRef]

45. Steg, L.; Vlek, C. Encouraging pro-environmental behaviour: An integrative review and research agenda. J. Environ. Psychol. 2009, 29, 309-317. [CrossRef]

46. Turaga, R.M.R.; Howarth, R.B.; Borsuk, M.E. Pro-environmental behavior. Ann. N. Y. Acad. Sci. 2010, 1185, 211-224. [CrossRef] [PubMed]

47. Whitmarsh, L.; O'Neill, S. Green identity, green living? The role of pro-environmental self-identity in determining consistency across diverse pro-environmental behaviours. J. Environ. Psychol. 2010, 30, 305-314. [CrossRef]

48. Puspita, G.C. Investigating the Intention of Female Consumers for Purchasing Green Skincare by Using the Pro-Environmental Planned Behavior Model; Institut Teknology Sepuluh Nopember: Surabaya, Indonesia, 2017.

49. Fransson, N.; Gärling, T. Environmental concern: Conceptual definitions, measurement methods, and research findings. J. Environ. Psychol. 1999, 19, 369-382. [CrossRef]

50. Ajzen, I. Constructing a TPB Questionnaire: Conceptual and Methodological Considerations. Conference Proceeding. 2002. Available online: https://pdfs.semanticscholar.org/0574/ b20bd58130dd5a961f1a2db10fd1fcbae95d.pdf (accessed on 22 March 2018).

51. Sudiyanti, S. Predicting Women Purchase Intention for Green Food Products in Indonesia; Universitetet i Agder, University of Agder: Kristiansand, Norway, 2009. 
52. Zhou, Y.; Thøgersen, J.; Ruan, Y.; Huang, G. The moderating role of human values in planned behavior: The case of chinese consumers' intention to buy organic food. J. Consum. Mark. 2013, 30, 335-344. [CrossRef]

53. Schielke, S.; Altobelli, C.F. Consumer Greenwashing: Using the Theory of Planned Behaviour to Explain Unethical Consumer Behaviour. Institut für Marketing Diskussionsbeitrag Nr. 5. 2012. Available online: http:/ / docplayer.net/42361097-Consumer-greenwashing-using-the-theory-of-planned-behaviourto-explain-unethical-consumer-behaviour.html (accessed on 22 March 2018).

54. National Institutes of Health. Consumer Health Informatics Research Resource. Available online: https: / / chirr.nlm.nih.gov / (accessed on 22 March 2018).

55. Nevitt, J.; Hancock, G.R. Performance of bootstrapping approaches to model test statistics and parameter standard error estimation in structural equation modeling. Struct. Equ. Model. 2001, 8, 353-377. [CrossRef]

56. Schreiber, J.B.; Nora, A.; Stage, F.K.; Barlow, E.A.; King, J. Reporting structural equation modeling and confirmatory factor analysis results: A review. J. Educ. Res. 2006, 99, 323-338. [CrossRef]

57. Denscombe, M. The Good Research Guide: For Small-Scale Social Research Projects; McGraw-Hill Education: London, UK, 2014.

58. Goforth, C. Using and Interpreting Cronbach's Alpha. Available online: http:// data.library.virginia.edu (accessed on 26 March 2018).

59. Streiner, D.L. Starting at the beginning: An introduction to coefficient alpha and internal consistency. J. Personal. Assess. 2003, 80, 99-103. [CrossRef] [PubMed]

60. Cronbach, L.J. Coefficient alpha and the internal structure of tests. Psychometrika 1951, 16, 297-334. [CrossRef]

61. Carmines, E.G.; Zeller, R.A. Reliability and Validity Assessment; Sage Publications: Thousand Oaks, CA, USA, 1979; Volume 17.

62. Fornell, C.; Larcker, D.F. Evaluating structural equation models with unobservable variables and measurement error. J. Mark. Res. 1981, 39-50. [CrossRef]

63. Bove, L.L.; Pervan, S.J.; Beatty, S.E.; Shiu, E. Service worker role in encouraging customer organizational citizenship behaviors. J. Bus. Res. 2009, 62, 698-705. [CrossRef]

64. Hair, J.F., Jr.; Hult, G.T.M.; Ringle, C.; Sarstedt, M. A Primer on Partial Least Squares Structural Equation Modeling (PLS-SEM); Sage Publications: Thousand Oaks, CA, USA, 2016.

65. Ek, Å.; Runefors, M.; Borell, J. Relationships between safety culture aspects-a work process to enable interpretation. Mar. Policy 2014, 44, 179-186. [CrossRef]

66. Field, A. Reliability Analysis. Research Methods II. 2006, pp. 1-7. Available online: https://www. discoveringstatistics.com/repository/reliability.pdf (accessed on 22 March 2018).

67. Hair, J.F.; Black, W.C.; Babin, B.J.; Anderson, R.E.; Tatham, R.L. Multivariate Data Analysis, 6th ed.; Pearson Prentice Hall: Uppersaddle River, NJ, USA, 2006.

68. Lin, S.-C.; Persada, S.F.; Nadlifatin, R. A Study of Student Behavior in Accepting the Blackboard Learning System: A Technology Acceptance Model (TAM) Approach. In Proceedings of the 2014 IEEE 18th International Conference on Computer Supported Cooperative Work in Design (CSCWD), Hsinchu, Taiwan, 21-23 May 2014; IEEE: Piscataway, NJ, USA, 2014; pp. 457-462.

69. Alarcón, D.; Sánchez, J.A.; De Olavide, U. Assessing convergent and discriminant validity in the ADHD-R IV rating scale: User-written commands for Average Variance Extracted (AVE), Composite Reliability (CR), and Heterotrait-Monotrait ratio of correlations (HTMT). In Composite Reliability (CR), and Heterotrait-Monotrait Ratio of Correlations (HTMT), Proceedings of the Spanish Stata Meeting, Madrid, Spain, 22 October 2015; Pablo de Olavide University: Sevilla, Spain, 2015; pp. 1-39.

70. Bradley, J.V. Robustness? Br. J. Math. Stat. Psychol. 1978, 31, 144-152. [CrossRef]

71. Hair, J.F.; Black, W.C.; Babin, B.J.; Anderson, R.E.; Tatham, R.L. Multivariate Data Analysis; Prentice Hall: Upper Saddle River, NJ, USA, 1998; Volume 5.

72. Times, S. List of Countries by Projected Gdp per Capita. Available online: http://statisticstimes.com/ economy/countries-by-projected-gdp-capita.php (accessed on 26 March 2018).

(C) 2018 by the authors. Licensee MDPI, Basel, Switzerland. This article is an open access article distributed under the terms and conditions of the Creative Commons Attribution (CC BY) license (http://creativecommons.org/licenses/by/4.0/). 